\title{
Lake contamination models for evolution towards steady state
}

\author{
Johan C. VAREKAMP \\ Earth \& Environmental Sciences, Wesleyan University, Middletown CT USA 06459-0139 \\ e-mail: jvarekamp@wesleyan.edu
}

\begin{abstract}
Most lakes are in an average steady state for water but contaminants may not yet have reached steady state or are gradually being flushed out in a clean-up program. The evolution towards steady state for fully mixed or stratified lakes can be described by basic equations of mass flow. The time-concentration paths for fully mixed lakes are asymptotic toward a steady state concentration, which is reached in about 6 contaminant residence times (and clean-up also takes about 6 residence times). Stratified lakes also evolve towards a whole-lake steady state concentration but show oscillating patterns of concentration versus time, with the amplitude and dampening period depending on the volume ratio of epilimnion to total lake volume. In most natural lakes, the compositional contrast between epilimnion and hypolimnion will become almost erased in 2-4 residence times. An acid lake in North-Patagonia is used as an example of contamination of a thermally stratified lake by volcanic effluents.
\end{abstract}

Key words: lake contamination, physical lake models

\section{INTRODUCTION}

The element and water dynamics in lakes are commonly treated as pseudo steady states (Gibson et al. 2002), but for many contaminants, a lake may not yet have reached steady state. Possibly more important, clean up times of lakes must be estimated by environmental managers (Stumm 1985), and the basics of contaminant dynamics in lakes that are evolving towards a steady state can be treated straightforward from first principles.

The water residence time, $\mathrm{R}$, in a lake can only be defined if the lake is in steady state for water (total input = total output), and then equals $\mathrm{R}=\mathrm{M} / \mathrm{F}$, where $\mathrm{M}$ is the lake mass, and $\mathrm{F}$ the total influx or total outflux of water. For piston flow, the $\mathrm{R}$ of water is the time required to replenish the complete body of water. Piston flow does not occur in the majority of lakes, and most lakes are mixed on a daily, seasonal or annual time scale dependent on climate and lake geometry. In the temperate climates, a seasonal thermal stratification is common, and the contamination history or clean-up of a lake can be derived through consideration of a set of expressions that can be solved analytically for the well-mixed case (Varekamp 1988) and numerically for a stratified case. The same approach can be used to estimate input fluxes from known contamination histories.

\section{CONTAMINANT DYNAMICS IN PERFECTLY- MIXED LAKES}

The change in the total mass of a conservative component $\mathrm{p}$ in a lake with mass $\mathrm{M}$ is expressed by:

$$
\mathrm{dP} / \mathrm{dt}=\mathrm{F}_{\mathrm{p}, \text { in }}-\mathrm{F}_{\mathrm{p}, \text { out }}
$$

where $\mathrm{P}$ is the resident amount of $\mathrm{p}$ in the reservoir and $F_{p, i n}$ and $F_{p, o u t}$ are respectively the contaminant fluxes in and out of the lake. As a first approximation, we take the influx of $p$ as a constant, $F_{p, i n}$. The outflux of $p$ depends on the $\mathrm{p}$ concentration in the lake and can be phrased as $k_{p} P$, where $k_{p}$ is a rate constant or the fraction of the resident contaminant mass that is removed per time unit. In general:

$$
\mathrm{k}_{\mathrm{p}}=\mathrm{F}_{\mathrm{p}, \text { out }} / \mathrm{P}
$$

where:

$$
\mathrm{F}_{\mathrm{p}, \text { out }}=\mathrm{F}^{*}{ }_{\mathrm{w}, \text { out }} \mathrm{C}_{\mathrm{p}}
$$

with $\mathrm{C}_{\mathrm{p}}=\mathrm{P} / \mathrm{M}$ and $\mathrm{F}^{*}{ }_{\mathrm{w} \text {,out }}$ is the sum of those water fluxes that carry the contaminant $\mathrm{p}$ (this may exclude, for instance, the evaporative water loss). Combination of these expressions leads to $\mathrm{k}_{\mathrm{p}}=\mathrm{F}^{*}{ }_{\mathrm{w}, \text { out }} / \mathrm{M}$, which is a constant while the system evolves towards steady state for a given substance. In general, $R_{p}=1 / k_{p}$, where $R_{p}$ is the residence time of the contaminant once the contaminant has reached steady state. Formally, we can not use the residence time concept for a component that has not yet reached steady state because the contaminant mass in the lake is still a time-dependent variable.

The solution to the expression:

$$
\mathrm{dP} / \mathrm{dt}=\mathrm{F}_{\mathrm{p}, \mathrm{in}}-\mathrm{k}_{\mathrm{p}} \mathrm{P}
$$

provides the fundamental equation that describes the progressive contamination or clean up of a lake with water in steady state and conservative behaviour of $p$. This differential equation can be solved (Varekamp 1988 ) with the boundary condition that at $t=0, C_{p}=C_{p}^{\text {init }}$ which leads to:

$$
C_{p}=C_{p}^{s s}\left(1-e^{-k t}\right)+C_{p}^{\text {init }} e^{-k t}
$$


If the lake was clean at the start $\left(\mathrm{C}_{\mathrm{p}}^{\mathrm{init}}=0\right)$, the second term in eq. 5 disappears. The general pattern of lake contamination shows an asymptote towards a constant contaminant concentration, $\mathrm{C}_{\mathrm{p}}^{\mathrm{ss}}$, the steady state contaminant concentration. When the reservoir reaches $\mathrm{C}^{\mathrm{ss}}{ }_{\mathrm{p}}$, the $\mathrm{p}$ outflux has become equal to the $\mathrm{p}$ influx and $\mathrm{dP} / \mathrm{dt}$ in eq. 1 has become zero (contaminant in steady state). The steady state concentration can be phrased as:

$$
\mathrm{C}_{\mathrm{p}}^{\mathrm{ss}}=\mathrm{F}_{\mathrm{p}, \text { in }} / \mathrm{k}_{\mathrm{p}} \mathrm{M} \text { or } \mathrm{F}_{\mathrm{p}, \text { in }} / \mathrm{F}^{*}{ }_{\mathrm{w} \text {,out }}
$$

Alternatively, equation 5 can be recast into:

$$
\mathrm{C}_{\mathrm{p}}=\mathrm{C}_{\mathrm{p}}^{\mathrm{ss}}\left(1-\mathrm{e}^{-\mathrm{t} / \mathrm{Rp}}\right)+\mathrm{C}_{\mathrm{p}}^{\mathrm{init}} \mathrm{e}^{-\mathrm{t} / \mathrm{Rp}}
$$

where $R_{p}$ is the contaminant residence time at steady state. I use a model lake of $100 \mathrm{~m}$ depth, a water residence time of 100 months, and a mass of $100,000 \mathrm{~m}^{3}$ and the time concentration path for such a lake is shown in figure 1 . If the lake started with a concentration of $\mathrm{C}^{\text {init }}$, another concentration-time path is followed but the steady-state concentration will be the same (Fig. 1).



Fig. 1. Time-composition trends for a fully mixed lake, starting at 0 and $5 \mathrm{ppm}$ and evolving towards a steady state concentration of $10 \mathrm{ppm}$. Also shown is the evolution trend for the epilimnion only with a thermocline at $10 \mathrm{~m}$ depth.

The time to reach steady state in a perfectly mixed reservoir can be derived from the time that it takes for the term $\mathrm{e}^{\mathrm{t} / \mathrm{R}}$ to go to $\sim$ zero, which occurs if $\mathrm{t}=\sim 6 \mathrm{R}$, when $99.75 \%$ of $\mathrm{C}_{\text {ssp }}$ has been reached (600 months in the case of the model lake). So as a general rule, wellmixed lakes that are polluted by a constant influx of a contaminant will reach steady state after about 6 contaminant residence times. The same is true for clean-up, and contaminant flushing times equal about 6 contaminant residence times. The steady state concentration is independent of lake volume (Fig. 1 example for small volume epilimnion only) and only a function of pollutant input and water outflow rate. The lake volume of course does impact the time to reach that steady state concentration. If the water is not in steady state, the lake volume will vary and numerical solutions have to be developed to obtain time-concentration paths for a pollutant in such lakes (Varekamp 1988). The solution to eq. 4 can also be found numerically using an incremental method with a time step $\Delta t$ between $\mathrm{P}_{\mathrm{t}}$ and $\mathrm{P}_{\mathrm{t}-\Delta \mathrm{t}}$ according to $\mathrm{P}_{\mathrm{t}}=\mathrm{P}_{\mathrm{t}-\Delta \mathrm{t}}+\Delta \mathrm{t}\left(\mathrm{F}_{\mathrm{p}, \text { in }}-\mathrm{K}_{\mathrm{p}} \mathrm{P}_{\mathrm{t}-\Delta \mathrm{t}}\right)$ and $\mathrm{C}_{\mathrm{t}}=\mathrm{P}_{\mathrm{t}} / \mathrm{M}$.

\section{CONTAMINANT DYNAMICS IN STRATIFIED LAKES}

For lakes that have a seasonal stratification and a contaminant inlet and water outlet only in the epilimnion, numerical solutions can be developed to follow the evolution of the contaminant concentrations over the time. I assume first a monomictic pattern (half of time stratified, half of the time fully mixed). I assume a whole-lake water steady state, a constant contaminant input of $10 \mathrm{~kg} \mathrm{p} / \mathrm{month}$, and a permanently well mixed epilimnion. A numerical model is developed for this lake with either a $25 \mathrm{~m}$ or $10 \mathrm{~m}$ deep thermocline. After a half year, the lake overturns and evolves for 6 months as a perfectly mixed basin. The time-concentration path during the first 6 months in the epilimnion is calculated numerically with a time step of 1 month $(\Delta t=1)$ from:

$$
\mathrm{C}_{\mathrm{t}}^{\mathrm{e}}=\left(\mathrm{M}_{\mathrm{e}} \times \mathrm{C}_{\mathrm{t}-1}^{\mathrm{e}}+\mathrm{F}_{\mathrm{p}, \text { in }}-\mathrm{F}_{\mathrm{w}, \text { out }} \times \mathrm{C}_{\mathrm{t}-1}^{\mathrm{e}}\right) / \mathrm{Me}
$$

and at the end of that period the lake is mixed according to:

$$
\mathrm{C}_{\mathrm{p}}=\mathrm{M}_{\mathrm{e}} / \mathrm{M}_{1} \times \mathrm{C}_{\mathrm{e}}+\mathrm{M}_{\mathrm{h}} / \mathrm{M}_{1} \times \mathrm{C}_{\mathrm{h}}
$$

where the sub/superscripts $\mathrm{e}, \mathrm{h}$ and $\mathrm{l}$ refer to the epilimnion, hypolimnion and whole lake. The concentration calculated from eq. 8 is then used as the initial concentration in the calculations for the next 6 months, which uses a well-mixed body of mass $\mathrm{M}_{1}$ substituted into eq. 7. At the beginning of the second year, the epilimnion evolution starts again with a new initial concentration of the well-mixed lake at the end of the first year, and the hypolimnion remains fixed at that value for 6 months. The results for the stratified scenario of a lake with a $25 \mathrm{~m}$ deep thermocline show a pattern of a dampened oscillator, with the contaminant concentrations in the epilimnion quickly rising and then falling back to concentrations close to those that would have occurred in a fully-mixed scenario (Fig. 2 right). Careful examination of figure 2 shows that the stratified lake curve segments for complete mixing plot slightly below that of the permanently well-mixed lake concentrations. This is a result of the enhanced export of the contaminant from the epilimnion: more contaminant is exported per time unit from the epilimnion during the peak concentration periods than in the case of the fully mixed lake with its lower contaminant concentration. The pattern for a lake with an epilimnion of $10 \mathrm{~m}$ and a $90 \mathrm{~m}$ thick hypolimnion shows, as expected, a more extreme oscillating concentration-time pattern (Fig. 2 left) and the well-mixed curve segments plot further below that of the fully mixed lake. 

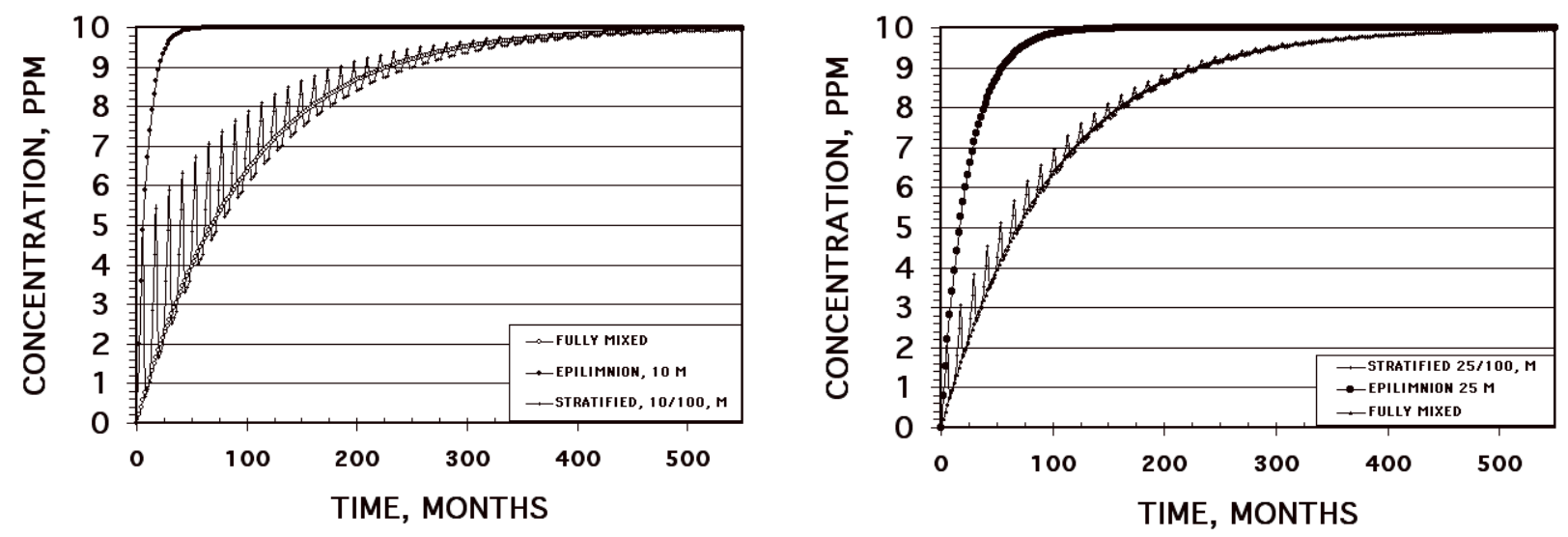

Fig. 2. Time concentration paths for the model lake with $10 \mathrm{~m}$ deep thermocline (left) and a $25 \mathrm{~m}$ deep thermocline (right). The fully mixed path and epilimnion-path only are shown for reference. Note the small offset between fully mixed and partially mixed pattern as a result of enhanced pollutant export from the epilimnion in the stratified case.

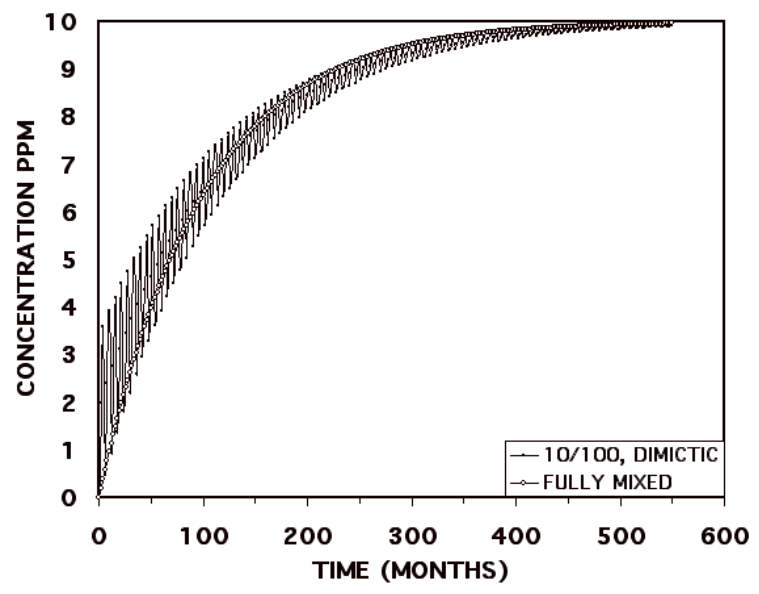

Fig. 3. Time-concentration curve for the model lake with dimictic behaviour.

A pattern for a dimictic lake is shown in figure 3, and here the fully-mixed evolution curve is even more discordant from the average pattern of the stratified lake. The oscillation in concentration is dampened over time during evolution of a stratified lake and the ratio of maximum epilimnion concentration over the fullymixed concentration during the lake evolution goes to 1 at a rate that depends on the volume of the epilimnion relative to that of the whole lake (Fig. 4).

The calculated results show (Fig. 4) that lakes with a relatively large epilimnion fairly quickly erase the difference between epilimnion and hypolimnion. Lakes with a shallow epilimnion take longer to equilibrate between epi- and hypolimnion, but in all cases the two layers reach a common contaminant concentration faster than the evolution time to steady state for the whole lake. For the 25/100 scenario, the difference between the two layers is almost gone at about 2-3 residence

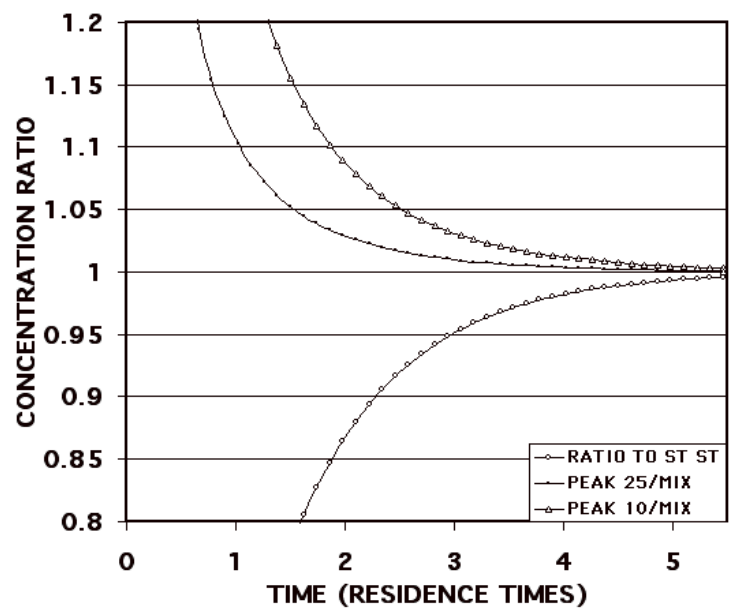

Fig. 4. Evolution towards steady state expressed as a ratio of steady state concentration and actual concentration (lower curve) and evolution of the maximum compositional contrast between epilimnion and hypolimnion for two cases (upper two curves).

times, whereas it takes $\sim 6$ residence times to reach steady state.

\section{LAKE CAVIAHUE, PROVINCE OF NEUQUEN, ARGENTINA}

Lake Caviahue $37.5^{\circ} \mathrm{S}, 71.1^{\circ} \mathrm{N}$ ) is a large, two-finger glacial lake that is contaminated by acid discharges of hot springs on Volcan Copahue (Delpino et al. 1997; Herman 1998; Pedrozo et al. 2001; Varekamp et al. 2001; Wendt-Potthoff \& Koschorreck 2001). Water was sampled in the lake at ten meter intervals for several years $(1997$ - 1999) as well as in the inflowing acid river (Upper Rio Agrio). The water flux of the Upper Rio Agrio was measured in a river cross section, using a water flow meter in a composite of several depth-width transects in the river. The width-depth-flow-rate data from each width segment were cumulated to obtain the 


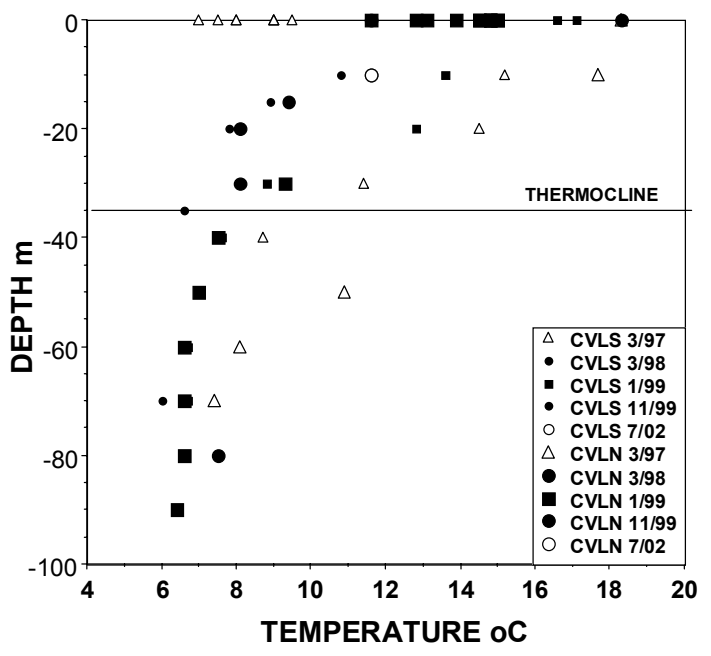

Fig. 5. Temperature-depth profiles for different years in Lake Caviahue. The mean thermocline is at $\sim 35$ depth; hypolimnion temperatures have been constant at 6-9 ${ }^{\circ} \mathrm{C}$. CLVS-south arm; CLVN-north arm.

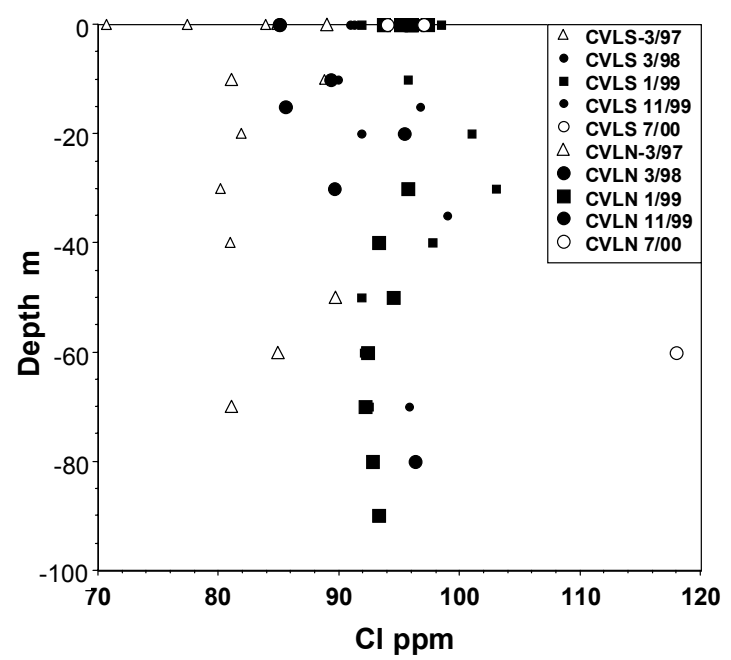

Fig. 6. Chloride-depth profiles for Lake Caviahue, showing a lack of chemical stratification but a progressive increase in $\mathrm{Cl}^{-}$ concentration over time.

Tab. 1. Representative chemical analyses $\left(\mathrm{mg} \mathrm{l}^{-1}\right)$ of Lake Caviahue $(\mathrm{CVLN}=$ northern arm; CVLS $=$ southern arm) surface waters and waters at a depth of $\sim 40 \mathrm{~m}$ from 1997-1999. Also shown is an analysis of the Upper Rio Agrio (URA) at the bridge in Caviahue at the entrance of Lake Caviahue.

\begin{tabular}{lcccccccc}
\hline & URA-22 & CVL-3 & CVLS-4 & CVLN 98 & CVLN-0 & CVLS-4 & CVLN-0 & CVLS-35 \\
\hline Depth $(\mathrm{m})$ & 0 & 0 & 40 & 0 & 0 & 40 & 0 & 35 \\
Date $(\mathrm{m} / \mathrm{d} / \mathrm{y})$ & $3 / 16 / 97$ & $3 / 17 / 97$ & $3 / 18 / 97$ & $3 / 14 / 98$ & $1 / 11 / 99$ & $1 / 8 / 99$ & $11 / 17 / 99$ & $11 / 17 / 99$ \\
$\mathrm{pH}$ & 1.47 & 2.44 & 2.48 & 2.30 & 2.23 & 2.36 & 2.00 & 2.01 \\
$\mathrm{Temp} .\left({ }^{\circ} \mathrm{C}\right)$ & 16.2 & 18.3 & 8.7 & 17.0 & 14.8 & 7.6 & 11.6 & 6.6 \\
$\mathrm{Cl}$ & 1656 & 85 & 81 & 85 & 96 & 98 & 97 & 99 \\
$\mathrm{SO}_{4}$ & 7736 & 349 & 317 & 352 & 471 & 470 & 457 & 480 \\
$\mathrm{Al}$ & 618 & 25.9 & 24.9 & 29.0 & 32.5 & 30.2 & 30.2 & 32.3 \\
$\mathrm{Fe}$ & 350 & 15.3 & 16.7 & 18.3 & 20.4 & 20.2 & 19.4 & 21.8 \\
$\mathrm{Mg}$ & 162 & 14.0 & 13.0 & 13.6 & 14.5 & 14.5 & 14.3 & 14.7 \\
$\mathrm{Ca}$ & 236 & 20.2 & 18.1 & 20.0 & 21.4 & 20.1 & 21.9 & 22.8 \\
$\mathrm{Na}$ & 184 & 11.6 & 9.9 & 13.1 & 13.9 & 13.2 & 14.9 & 12.7 \\
$\mathrm{~K}$ & 128 & 5.9 & 5.3 & 6.8 & 7.5 & 7.0 & 7.9 & 8.1 \\
$\mathrm{Si}$ & 48 & 17.5 & 17.3 & 12.7 & 14.1 & 13.8 & 13.5 & 13.9 \\
$\mathrm{Mn}$ & 8.5 & 0.7 & 0.7 & 0.3 & 0.9 & 0.8 & 0.7 & 0.7 \\
\hline
\end{tabular}

total water flux. The estimated error based on multiple measurements in the same river stretch is about $\pm 15 \%$.

The $\mathrm{pH}$ was measured with a Mettler 1260 Autotitrator in the laboratory after collection. The chemical composition of the water samples was analyzed with an ICP-AES (Perkin \& Elmer, Plasma 400) and a Dionex 5500 Ion Chromatograph. Precision of the chemical analyses is $\pm 4 \%$, as determined by repeat analyses of samples and accuracy was ascertained by analyses of validation samples of inhouse standards as well as commercial standards.

The lake has a volume of $0.474 \mathrm{~km}^{3}$, a maximum depth close to $100 \mathrm{~m}$ and a meteoric water input of 0.3-5 $\mathrm{m}^{3} \mathrm{~s}^{-1}$ (Rapacioli 1985). During the austral summer, the lake is thermally stratified with a thermocline at $\sim 35 \mathrm{~m}$ depth (Fig. 5), but it has been chemically homogeneous since 1997 (Fig. 6). During the austral winter, the lake is well-mixed (monomictic, Pedrozo et al. 2001). The mean water residence time was calculated at 2.6 years (Rapacioli 1985), using estimated mean annual discharge values of the two main input rivers and the whole lake volume. The seasonal lake stratification and very strong seasonal fluctuations in river discharge make such a mean water residence time value difficult to evaluate. The source of cations and acidity for Lake Caviahue is the Upper Rio Agrio (Tab. 1), an acid river fed by extremely acidic ( $\mathrm{pH} \sim 0.35$ hot springs high up the slopes of Copahue volcano (Varekamp et al. 2001). Although the discharge of the Upper Rio Agrio fluctuates with precipitation and glacier melting, the $\mathrm{Cl}^{-}$flux has been relatively constant over time because the volcanic springs flow at a steady rate. The $\mathrm{Cl}^{-}$flux between 1997 and 1999 was obtained by measuring the river flux rate and analyzing the water at that position in the river (Tab. 2). The mean flux is about $13,400 \mathrm{t} \mathrm{Cl}^{-} \mathrm{y}^{-1}$ and the mean $\mathrm{Cl}^{-}$concentration in the lake was about $93 \mathrm{mg} \mathrm{l}^{-1}$ 
Tab. 2. Some representative element fluxes measured at the bridge in Caviahue in the Upper Rio Agrio. The apparent element residence times $\left(\mathrm{RT}^{*}=\mathrm{M}_{\mathrm{w}} \mathrm{C}_{\mathrm{el}} / \mathrm{F}_{\mathrm{el}}\right.$ in $)$ were calculated from analyses of Lake Caviahue waters, lake volume and element input fluxes. The average of all the mean $\mathrm{RT}^{*}$ values is 3.5 years.

\begin{tabular}{lccccccc}
\hline Date & $\begin{array}{c}\text { Water flux } \\
\left(\mathrm{m}^{3} \mathrm{~s}^{-1}\right)\end{array}$ & $\begin{array}{c}\mathrm{Cl} \text { flux } \\
\left(\mathrm{t} 10^{3} \mathrm{y}^{-1}\right)\end{array}$ & $\begin{array}{c}\mathrm{RT}^{*} \mathrm{Cl} \\
(\mathrm{y})\end{array}$ & $\begin{array}{c}\mathrm{S} \text { flux } \\
\left(\mathrm{t} 10^{3} \mathrm{y}^{-1}\right)\end{array}$ & $\begin{array}{c}\mathrm{RT} * \mathrm{~S} \\
(\mathrm{y})\end{array}$ & $\begin{array}{c}\mathrm{Mg} \text { flux } \\
\left(\mathrm{t} 10^{3} \mathrm{y}^{-1}\right)\end{array}$ & $\begin{array}{c}\mathrm{RT} * \mathrm{Mg} \\
(\mathrm{y})\end{array}$ \\
\hline $3 / 11 / 97$ & 0.3 & 13.2 & 3.0 & 21.1 & 2.5 & 1.3 & 5.1 \\
$1 / 7 / 99$ & 0.5 & 14.4 & 3.2 & 23.9 & 3.1 & 1.5 & 4.6 \\
$11 / 17 / 99$ & 2.3 & 12.6 & 3.7 & 25.1 & 3.0 & 2.0 & 3.4 \\
Mean & & 13.4 & 3.3 & 23.4 & 2.9 & 1.6 & 4.4 \\
\hline
\end{tabular}

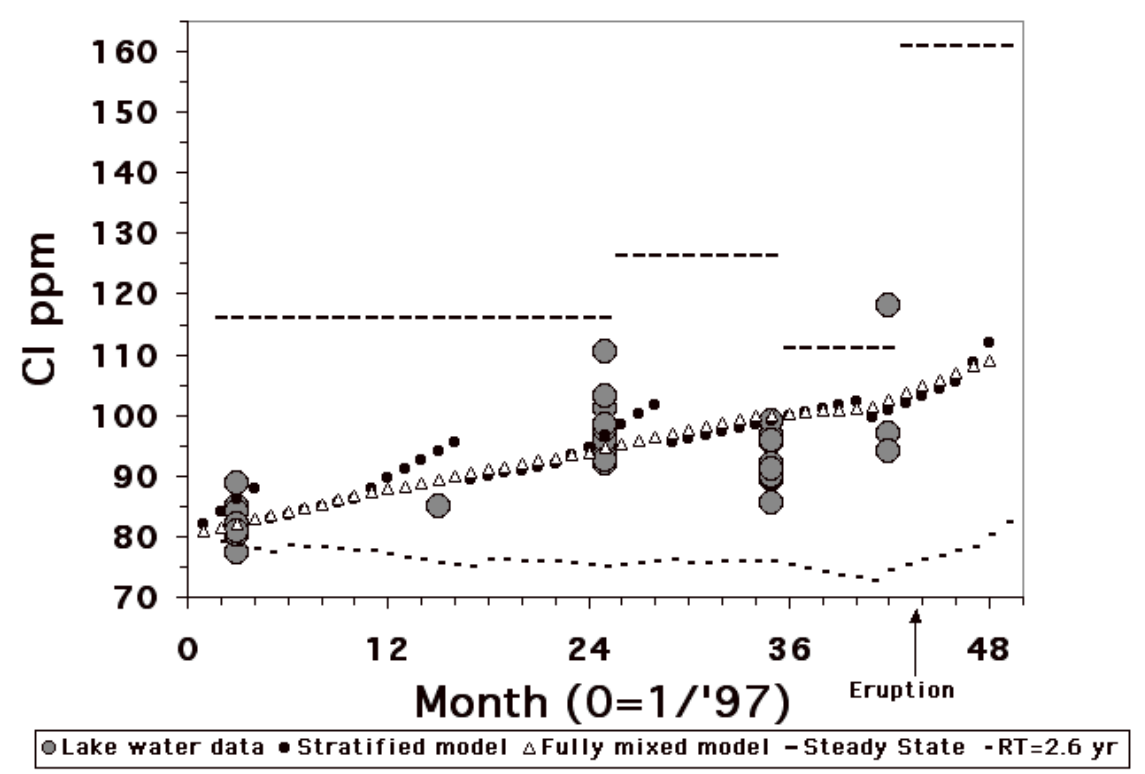

Fig. 7. Model data for Lake Caviahue using a 4 year residence time and $\mathrm{Cl}^{-}$fluxes that vary by year as given in table 2 . The lake water data are water column profiles for different years (selected analyses in table 1). The small black dots are the simulation for a monomictic lake with a thermocline at $35 \mathrm{~m}$ depth, whereas the small open triangles show the fully mixed time concentration path. The dashed curve at the bottom is the scenario for a 2.6 year water residence time. The dashed line segments at the top (Steady State) are the $\mathrm{Cl}$ steady state concentrations for the different $\mathrm{Cl}$ input using the 48 months residence time.

(Tab. 1), leading to a minimum mean apparent $\mathrm{Cl}^{-}$ residence time of 3.3 years. We use here the apparent residence time $\left(\mathrm{RT}^{*}\right)$ because the lake is possibly not in steady state for $\mathrm{Cl}$ and thus $\mathrm{RT}^{*}$ is a minimum value for R. A similar calculation for Mg (flux $1600 \mathrm{t} \mathrm{y}^{-1}$; 11/99 concentration is $14.2 \mathrm{mg} \mathrm{l}^{-1} \mathrm{Mg}$ ) yields an apparent mean residence time of about 4.4 years, whereas for sulphur we obtain a $\mathrm{RT}^{*}$ of 2.9 years. The mean concentrations of $\mathrm{Mg}, \mathrm{Cl}$ and $\mathrm{SO}_{4}$ all increased slightly over the period 1997-1999, but for $\mathrm{Cl}$ and $\mathrm{Mg}$ that change was not proportional to the variation in their input fluxes (Tabs 1,2). I therefore assume that the $\mathrm{Cl}$ and $\mathrm{Mg}$ input fluxes averaged over the three-year period provide a best mean input term (Tab. 2). The sulphur influx increased by $\sim 20 \%$ and the $\mathrm{SO}_{4}$ concentration in the lake increased by almost $30 \%$ over the period 1997 1999. These trends suggest that the lake is not yet in the steady state for any of the three substances, and part of these trends is a result of the evolution toward steady state and part is a reflection of the increase in the inputs. One-box evolution models for Lake Caviahue (Ouimette 2000) provided a mean residence time for $\mathrm{Cl}$ of about
4.5 years and one-box evolution model for $\mathrm{Mg}$ were presented by Varekamp et al. (2001). A two layer model for $\mathrm{Cl}$ using the equations given above with a 48 months (4 years) residence time shows good agreement with the 1997-1999 data from Lake Vaviahue (Fig. 7). The model reproduces the observed $\mathrm{Cl}$ data poorly when using the 2.6 year residence time of Rapacioli (Fig. 7). A water residence time of 4.3 years provides a best fit for the $\mathrm{SO}_{4}$ data (Fig. 8) and again, with the shorter water residence time I cannot reproduce the data arrays. A mean water residence time of about 4 years seems the optimal solution, and the lake then has not yet reached steady state for the three substances. The contamination has been going on long enough (3 residence time, 12 years or more?) at the current rate to largely wipe out the compositional contrast between epilimnion and hypolimnion.

\section{CONCLUSIONS}

Well-mixed lake systems evolve towards steady state according to an exponential function and take about 6 residence times to reach their steady state concentration. Strati- 




Fig. 8. Model data (open circles) for Lake Caviahue using a 4.3 year residence time and $\mathrm{SO}_{4}$ fluxes that vary by year (given in table 2). The lake water data (filled circles) are water column profiles for each year. The bottom curve (open squares) is a scenario for a residence time of 2.6 year. The dashed line segment at the top are $\mathrm{SO}_{4}$ steady state concentrations for the different $\mathrm{SO}_{4}$ inputs and the 4.3 year residence time.

fied lakes evolve with an oscillating pattern towards steady state, also over $\sim 6$ residence times. The compositional differences between epilimnion and hypolimnion are erased in about 2-4 residence times, the length of time depending on the ratio of epilimnion to whole lake volume. The acid Lake Caviahue in Patagonia shows no chemical stratification, strong seasonal thermal stratification (monomictic) and from lake parameters and input fluxes, it can be deduced that the lake has not yet reached chemical steady state for $\mathrm{Cl}, \mathrm{SO}_{4}$ and $\mathrm{Mg}$. Models that use the flux terms and lake analytical data lead to a mean water residence time of the lake of about $\sim 4$ years, somewhat longer than earlier estimates. This would suggest that the mean annual water input from the Upper Rio Agrio and the glacial melt water river Aqua Dulce unto Lake Caviahue is about 3.75 $\mathrm{m}^{3} \mathrm{~s}^{-1}$, well in the range of our data (Ouimette 1999), but slightly less than the estimated $5 \mathrm{~m}^{3} \mathrm{~s}^{-1}$ by Rapacioli (1985).

\section{ACKNOWLEDGMENTS}

This research was funded by the National Science Foundation (grant \# INT-9813912). Wesleyan University students Scott Herman, Andrew Ouimette, and Kathryn Flynn greatly contributed to the field work and analytical effort on Lake Caviahue.

\section{REFERENCES}

Delpino, D., J.C. Varekamp \& A. Bermudez. 1997. Influencia de sistema volcanico activo sobre un lago de origen gla- cial: Lago Caviahue, Neuquen, Argentina. In: Proceedings of $7^{\text {th }}$ International Conference on Lakes Conservation and Management, Bariloce, Argentina: 1-4.

Gibson, J.J., E.E. Papas \& P. McEachern. 2002. Quantitative comparison of lake throughflow, residency, and catchment runoff using stable isotopes: modeling and results from a regional survey of Boreal lakes. J. Hydrol., 262: 128-144.

Herman, S. 1998. The hydrogeochemistry of Copahue volcano, Argentina. BA thesis, Wesleyan University, Middletown, CT, USA: $94 \mathrm{pp}$.

Ouimette, A.P. 2000. Hydrothermal processes at an active volcano, Copahue, Argentina. MA thesis, Wesleyan University, Middletown, CT, USA: $220 \mathrm{pp}$.

Pedrozo, F., L. Kelly, M. Diaz, P. Temporetti, G. Baffico, R. Kringel, K. Friese, M. Mages, W. Geller \& S. Woefl. 2001 Water chemistry, plankton and trophic status of an Andean acidic lake of volcanic origin in Patagonia. Hydrobiologia, 452: 129-137.

Rapacioli, R. 1985. Lake Caviahue and its basin. Tech. Report, EPAS Gov. Office, Province of Neuquen, Argentina: $72 \mathrm{pp}$.

Stumm, W. (Ed.). 1985. Chemical processes in lakes. New York, John Wiley.

Varekamp, J.C. 1988. Lake-pollution modelling. J. Geological Education, 36: 4-9.

Varekamp, J.C., A.P. Ouimette, S.W. Herman, A. Bermudez \& D. Delpino. 2001 Hydrothermal element fluxes from Copahue, Argentina: a "beehive" volcano in turmoil. Geology, 29: 1059-1062.

Wendt-Potthoff, K., \& M. Koschorreck. 2001. Functional groups and activities of bacteria in a highly acidic volcanic mountain stream and lake in Patagonia, Argentina. Microbial Ecology, DOI: 10.1007/s00248-001-1030-8 (on-line). 